\title{
Tissue array analysis for the differentiation of gliosis from gliomas
}

\author{
V. MEDINA VILLAAMIL ${ }^{1}$, A. ÁLVAREZ GARCÍA ${ }^{2}$, G. APARICIO GALLEGO ${ }^{1}$, S.M. ${ }^{\text {a }}$ DÍAZ PRADO $^{1,3}$, \\ L.A. RIVAS LÓPEZ ${ }^{4}$, I. SANTAMARINA CAÍNZOS ${ }^{1}$, M. VALLADARES AYERBES ${ }^{5}$ and L.M. ANTÓN APARICIO ${ }^{3,5}$
}

\author{
${ }^{1}$ INIBIC; Departments of ${ }^{2}$ Pathology, and ${ }^{3}$ Neurosurgery, CHU A Coruña; \\ ${ }^{4}$ UDC Medical Department; ${ }^{5}$ Medical Oncology Department, A Coruña, Spain
}

Received November 24, 2010; Accepted March 9, 2011

DOI: $10.3892 / \mathrm{mmr} .2011 .462$

\begin{abstract}
The aim of this study was to provide a methodology to make a clear distinction between malignant tumors and morphologically similar benign processes, by examining the expression of EGFR, VEGF, HIF1- $\alpha$, survivin, Bcl-2 and p53 proteins. Four groups of patient samples were studied: group 1, low-grade astrocytomas (WHO grades I-II) $(n=6)$; group 2, peripheral area of high-grade astrocytomas (WHO grades III-IV) $(\mathrm{n}=5)$; group 3, gliomatosis cerebri $(\mathrm{n}=11)$; and group 4 , reactive gliosis $(\mathrm{n}=6)$. Tissue arrays (TAs) were designed to study apoptosis, angiogenesis and invasion-related proteins by immunohistochemistry (IHC). By means of nonparametric analysis (Mann-Whitney U test), EGFR staining was shown to be significantly lower in reactive gliosis than in the low- and high-grade astrocytomas $(\mathrm{p}=0.015$ and $\mathrm{p}=0.030$, respectively); Bcl-2 immunoreactivity was significantly higher in the gliomatosis cerebri samples than in the reactive processes $(\mathrm{p}=0.005)$; and finally, $\mathrm{Bcl}-2$ presented significantly lower expression levels in reactive gliosis compared to the peripheral areas of high-grade astrocytomas $(\mathrm{p}=0.004)$. The results indicate that Bcl-2 and EGFR may be useful in conducting differential diagnosis between the above groups, while the expression of the remaining antibodies does not appear to aid in distinguishing between the samples analyzed. The use of TAs to identify the protein expression profiles of biological markers related to different pathways was verified, and its potential as a discriminatory technique for everyday pathology procedures was demonstrated.
\end{abstract}

Correspondence to: Dr Vanessa Medina Villaamil, INIBIC, CHU A Coruña, 15006 A Coruña, Spain

E-mail: vanessa.medina.villaamil@sergas.es

Abbreviations: AC, astrocytoma, CNS, central nervous system; EGFR, epidermal growth factor receptor; GBM, glioblastoma multiform; GC, gliomatosis cerebri; HIF1- $\alpha$, hypoxia-inducible factor $1 \alpha$; IAP, inhibitor of apoptosis protein; IHC, immunohistochemistry; IRS, immunoreactivity score; PA, pilocytic astrocytoma; PBS, phosphate buffered saline; RG, reactive gliosis; TA, tissue array; VEGF, vascular endothelial growth factor

Key words: astrocytomas, Bcl-2, epidermal growth factor receptor, gliomatosis cerebri, reactive gliosis, survivin, tissue array

\section{Introduction}

Gliosis is characterized by hypertrophy, proliferation and increased expression of glial fibrillary acidic protein, which is a very sensitive indicator of disease processes. Reactive glial cells are therefore of fundamental importance to the neuropathologist $(1,2)$. It is debated whether gliomatosis cerebri (GC) is a pathologic entity or simply a group of histogenetically diverse tumors related only by a tendency towards widespread infiltration $(3,4)$. The unique neuropathological feature of GC is its tendency to be paucicellular in most locations, with loss of myelin and preservation of axons; axonal injury occurs late in the course of the disease, when increased cell density parallels increased axonal damage (5). GC is a specific entity, defined as a diffuse neoplastic glial cell infiltration of the brain that preserves the architecture of the normal surrounding tissues (6-8). It has an extremely variable prognosis, thus there is a need for molecular markers predictive of its outcome (9). There are few studies on GC in the literature due to the scarcity of tumor tissue available for such analysis $(8,10-15)$.

The relationship between gliomatosis cerebri and common focal gliomas is unclear at present. Due to uncertainties concerning the origin and pathogenesis of $\mathrm{GC}$, the current WHO classification includes this lesion in a separate section under the category 'glial tumors of uncertain origin' (16). The most problematic cases of reactive gliosis (RG) from neoplastic glial cell proliferation usually involve small fixed-tissue biopsy specimens from stereotactic biopsy, with inadequate morphologic support for differentiation using only histological criteria. The peripheral area of high grades of glial neoplasia closely resembles that of their cellular proliferation counterparts $(17,18)$. Therefore, pathologists often confront a complex diagnostic problem when differentiating between them. Given the importance of detailed histopathological evaluation as the necessary first-line technique to resolve this issue, complementary microtechniques or other auxiliary methods must be used (19).

Immunohistochemistry (IHC) was performed on tissue arrays (TAs) allowing for the evaluation of molecular targets in a large number of samples in parallel. The 2-mm diameter of the tissue cores preserved recognizable histological features, supplying more tissue surface for the evaluation of immunostaining $(20,21)$. The importance of differentiating RG from neoplasm cannot be stressed enough, since treatment is not only different, but also potentially injurious, if unsuitably 
Table I. Antibodies panel.

\begin{tabular}{lcccc}
\hline Antibody & Ig subclass & Dilution & Incubation & Company \\
\hline EGFR (clone H11) & Ig G1 & $1: 25$ & $30^{\prime}$ & Dako \\
VEGF (C-1) & Ig G2a & $1: 100$ & $30^{\prime}$ & Santa Cruz \\
HIF1- $\alpha$ (ab8366) & Ig G1 & $1: 1,500$ & Overnight & Abcam \\
Survivin (D-8) & Ig G2a & $1: 100$ & Overnight & Santa Cruz \\
Bcl-2 (clone 124) & Ig G1 & $1: 75$ & $30^{\prime}$ & Dako \\
p53 (clone DO7) & Ig G2b & $1: 500$ & $30^{\prime}$ & Dako \\
\hline
\end{tabular}

Dako, Dako Denmark A/S; Santa Cruz, Santa Cruz Biotechnology, Inc.; Abcam, Abcam Ltd., UK.

applied. Little is known regarding the molecular mechanisms that control reactive astrocytosis. Several observations indicate that it is a regulated process involving cytokines, inflammatory mediators, growth factors and physiological stimuli, such as hypoxia (22). Overexpression of epidermal growth factor receptor (EGFR) occurs in reactive astrocytes as a result of a broad range of central nervous system (CNS) insults (23). In the adult CNS, the EGFR pathway is absent and is activated following neuronal injury $(24,25)$.

Neoangiogenesis forms part of any reparative tissue process. Among its regulators, vascular endothelial growth factor (VEGF) is highly potent and specific, and acts by activating its related receptors on the endothelial cells, resulting in their proliferation, migration and metastasis. VEGF has been implicated in most physiological and pathological events $(26,22)$. The up-regulation of VEGF expression in response to reduced oxygen tension occurs by means of transcriptional and post-transcriptional mechanisms, in which hypoxia-inducible factor $1 \alpha(\mathrm{HIF} 1-\alpha)$ plays a crucial role.

To date, IHC to examine $\mathrm{p} 53, \mathrm{Bcl}-2$ and survivin protein in gliosis and gliomas using TA technology is lacking. The difference in p53 protein expression among tumors of grade I and other grades (II-IV) may be a plausible explanation for the differences in their biological behaviour. Reactive states should be deficient in the glioma-associated mutational damage that we would expect to be present in malignant neoplasia.

Wild-type p53 protein is present in a wide variety of normal cells, but has a very short half-life and is present in only low amounts (27), generally below the detection level of immunohistochemical methods. Normal brain tissue has not been shown to express p53 immunohistochemically (28). Somatic mutation of the p53 gene is a very frequent event in the development of glial neoplasia and, since mutant p53 proteins are often much more stable than wild-type p53 protein, a high level of mutant p53 protein accumulates (27).

The Bcl-2 proto-oncogene is a member of a growing family of genes that block apoptosis. Overexpression of Bcl-2 has also been noted in several glioma lines. Since normal astrocytes do not express Bcl-2 protein in vivo, its expression may be indicative of malignant transformation (29). Up-regulation of Bcl-2 within astrocytes is not uniquely associated with neoplastic transformation, as its appearance may also be noted in response to injury to the CNS (30).
Survivin is a member of the inhibitor of apoptosis protein (IAP) family via a pathway independent of $\mathrm{Bcl}-2$, and is also a potent regulator of mitosis. Although survivin has been found to be highly expressed in gliomas and is associated with tumorigenesis, progression and the poor prognosis of gliomas $(31,32)$, currently the understanding of the relationship between survivin expression and proliferation, apoptosis and glioma angiogenesis, as well as its correlation with other biomarkers of malignancy, is limited.

This report describes an initial investigation of a wide range of known astrocytoma (AC)-related markers, with the aim of determining whether they may be applied to address the crucial challenge of distinguishing between gliosis and glioma.

\section{Materials and methods}

Tissue samples. In order to retrospectively evaluate, by means of immunohistochemistry, a variety of AC-related markers, 28 brain specimens from 26 patients were obtained from the histopathological archives of the Department of Pathology of CHU A Coruña (A Coruña, Spain). The samples comprised surgical resections or biopsies obtained between 1993 and 2004. The Institutional Review Board of CHU A Coruña approved the retrospective review of the medical records and the use of the archived tumor specimens. The tumor samples were classified and graded according to the WHO criteria (16).

Four types of samples were examined, divided into four groups: group 1, low-grade ACs $(n=6)$ including 1 pilocytic astrocytoma (PA) specimen (WHO grade I) and 5 ACs (WHO grade II); group 2, high-grade $\mathrm{ACs}(\mathrm{n}=5)$ consisting of 5 specimens from the peripheral area of glioblastoma multiforme (GBM) (WHO grade IV); group 3, biopsy specimens from lesions associated with GCs $(n=11)$; group 4, biopsy specimens from lesions associated RGs $(n=6)$. Full clinical data were obtained from the clinicopathological databases. Viable areas of morphological interest in the specimens were identified by a pathologist. A tissue array apparatus (Durviz) was used to obtain tissue cores with a 2-mm diameter for the construction of a TA containing 48 samples (a $6 \times 8$ matrix was designed).

To blend together the paraffin wax from the recipient block and the tissue cylinders, the TA was incubated at $60^{\circ} \mathrm{C}$ 
for $10 \mathrm{~min}$. After incubation, the tissue cylinders were labelled with the block using a glass slide. Sections $(4 \mu \mathrm{m})$ were obtained using a rotary microtome (Leica RM 2155), mounted on silanized slides and incubated until use for IHC.

Immunohistochemical study. The primary antibodies used are listed in Table I. As indicated in the literature, the working dilution was determined using positive controls: for EGFR and p53, epidermoid lip carcinoma; for VEGF and survivin, breast carcinoma; for HIF1- $\alpha$, grade IV glioma; and for Bcl-2, normal tonsil tissue. Additional sections, run in parallel with the omission of the primary antibody, served as negative controls.

For IHC, the sections were deparaffinized in xylene and rehydrated in decreasing concentrations of ethanol, then washed in deionized water. EGFR antigen retrieval was performed by incubating the sections in Proteinase $\mathrm{K}$ readyto-use solution ( $\mathrm{pH}$ 7.5-7.7) (Dako Denmark A/S) for $5 \mathrm{~min}$; for VEGF, survivin and HIF1- $\alpha$, sections were boiled in a pressure cooker in target retrieval solution (citrate buffer, $\mathrm{pH}$ 6.0) (Dako) for $25 \mathrm{~min}$; and finally, for Bcl-2 and p53, sections were boiled in a pressure cooker (2100 Retriever ${ }^{\mathrm{TM}}$, PickCell Laboratories) in $1 \mathrm{mM}$ EDTA ( $\mathrm{pH} \mathrm{9.0)} \mathrm{for} 25 \mathrm{~min}$. After cooling, the specimens were rinsed three times in deionized water. Sections were then treated with peroxidase blocking reagent (ready-to-use) (Dako) for $10 \mathrm{~min}$ to eliminate endogenous peroxidase activity. After three 30-min washes in phosphate buffered saline (PBS) (pH 7.4) (Sigma) and Tween-20, specific primary antibodies were applied at the dilutions shown in Table I.

After incubation, the slides were washed with PBS and Tween-20. The reaction was visualized using the Dako Envision system with diaminobenzidine as the chromogen according to the manufacturer's instructions. Finally, the samples were washed again in deionized water, then counterstained with hematoxylin, dehydrated and mounted in DePeX $\left(\right.$ Gurr $\left.^{\circledR}\right)$.

Semi-quantification of antibody staining. The immunoreactivity score (IRS) was evaluated by multiplying the percentage of positive cells (scored as $0,<1 \% ; 1,1-24 \% ; 2,25-49 \% ; 3$, $50-74 \%$; and $4, \geq 75 \%$ ) by the staining intensity (scored as 1 , weak; 2 , moderate; and 3 , intense staining).

Statistical analysis. Data are expressed as the mean \pm standard deviation (SD). The statistical significance of the differences found was evaluated at the $95 \%$ confidence level by the non-parametric Mann-Whitney $U$ test. p-values $<0.05$ were considered the cut-off point for significance. Statistical analyses were performed using SPSS 15.0 for Windows.

\section{Results}

EGFR staining. In group 1, no EGFR staining was observed in the PA sample, while the grade II ACs showed immunoreactivity to the EGFR monoclonal antibody on the cell membrane of the tumor cells, and had the highest IRS score (IRS=3) among the EGFR-stained proteins. In group 2, EGFR expression was detected in $83 \%$ (5/6) of the peripheral area GBM samples, with the most intense staining in areas of high cellular density. Positive staining was not observed in necrotic areas. None of the $11 \mathrm{GC}$ or 6 RG samples in groups 3 and 4 exhibited EGFR expression (Fig. 1A-C).

VEGF staining. No VEGF monoclonal antibody staining was observed in the group 1 low-grade AC or PA samples. In the group 2 high-grade AC samples, immunoreactivity to VEGF was detected on the endothelial cell surface, increasing with vascular proliferation. Cytoplasmic staining of neoplastic cells was observed in $40 \%(2 / 5)$ of the group 2 samples, and $54.5 \%$ $(6 / 11)$ of the group 3 GC samples. In the group 4 RG specimens, staining was observed in $33.3 \%(2 / 6)$ of the samples in both the cytoplasm of reactive astrocytes and in ganglionar cells (Fig. 2A-C).

HIF1- $\alpha$ staining. No HIF1- $\alpha$ staining was observed in the group 1 low-grade AC or PA samples. By contrast, positive staining was observed in $60 \%(3 / 5)$ of the group 2 high-grade AC samples, and $36 \%$ (4/11) of the group 3 GC specimens. None of the group 4 RG samples exhibited HIF1- $\alpha$ expression.

Survivin staining. Only $20 \%(1 / 5)$ of the samples from the group 2 peripheral area of GBM specimens and 18\% (2/11) of the group $3 \mathrm{GC}$ samples were observed to be positive for nuclear survivin staining (Fig. 2D).

Bcl-2 staining. Positive staining for $\mathrm{Bcl}-2$ was observed in $50 \%(3 / 6)$ of the group 1 low-grade AC and PA samples. In the group 2 high-grade ACs, all the samples were positive for Bcl-2 (clone 124), except for one which was assessed as not valuable. Cytoplasmic staining, characterized by a brown reaction in the astrocytes and histiocytic cells, was visualized in $72.7 \%(8 / 11)$ of the group $3 \mathrm{GC}$ samples. None of the group $4 \mathrm{RG}$ samples exhibited Bcl-2 expression (Fig. 1D and E).

p53 staining. A positive nuclear reaction for p53 (clone DO7) was observed in only one group $3 \mathrm{GC}$ and one group $4 \mathrm{RG}$ sample (Fig. 2E and F).

Expression of markers of invasion, angiogenesis and apoptosis. To further investigate the expression of the EGFR, VEGF, HIF1- $\alpha$, survivin and p53 protein markers in the samples, and in order to identify the molecular characteristics that differentiate reactive from neoplastic astrocytes, TA experiments were performed using the 28 biopsy specimens from 26 patients. The mean $\pm \mathrm{SD}$ of the expression of each protein is shown in Fig. 3.

Notably, semi-quantitative analysis of the proteins revealed that $\mathrm{Bcl}-2$ oncoprotein expression was statistically lower in the group $4 \mathrm{RG}$ samples compared to the group 2 samples from the peripheral areas of GBM (Mann-Whitney U test, $p=0.004$ ) and compared to the group 3 GC specimens ( $p=0.005)$ (Fig. 4). There were no statistically significant differences in Bcl-2 expression $(\mathrm{p}=0.065)$ between the group 1 low-grade $\mathrm{AC}$ and group 4 specimens. EGFR intrinsic tyrosine kinase expression was also significantly lower in group 4 compared to group 2 $(\mathrm{p}=0.030)$ and compared to group $1(\mathrm{p}=0.015)$ (Figs. 3 and 4$)$.

No statistically significant differences in the expression of VEGF, HIF1- $\alpha$, survivin and p53 were found among the tissues samples. Consequently, the expression of these 

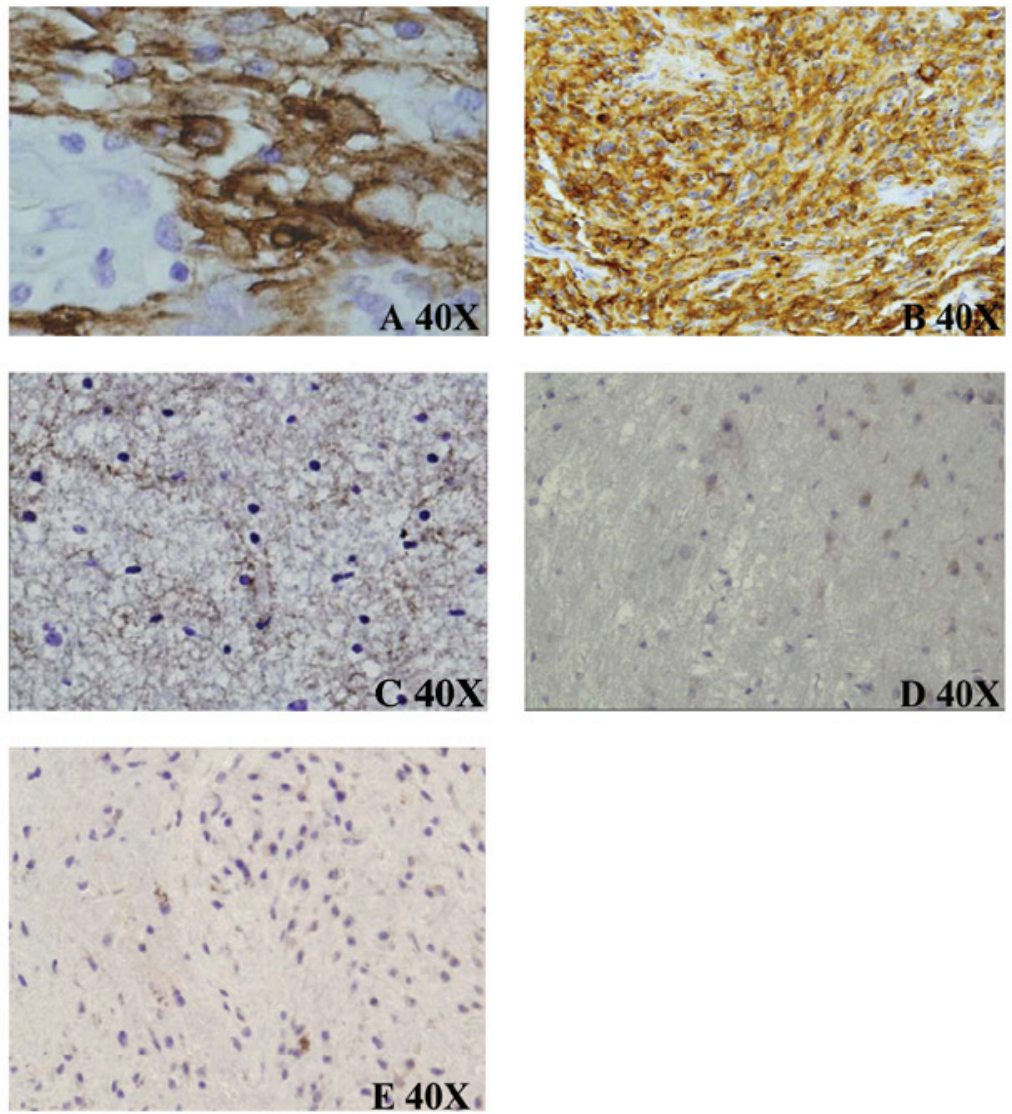

Figure 1. EGFR staining in (A) group 1, (B) group 2 and (C) group 3. (D) Bcl-2 in GC, IRS=2. (E) Bcl-2 in RG, no reaction. Magnification, $x 40$.
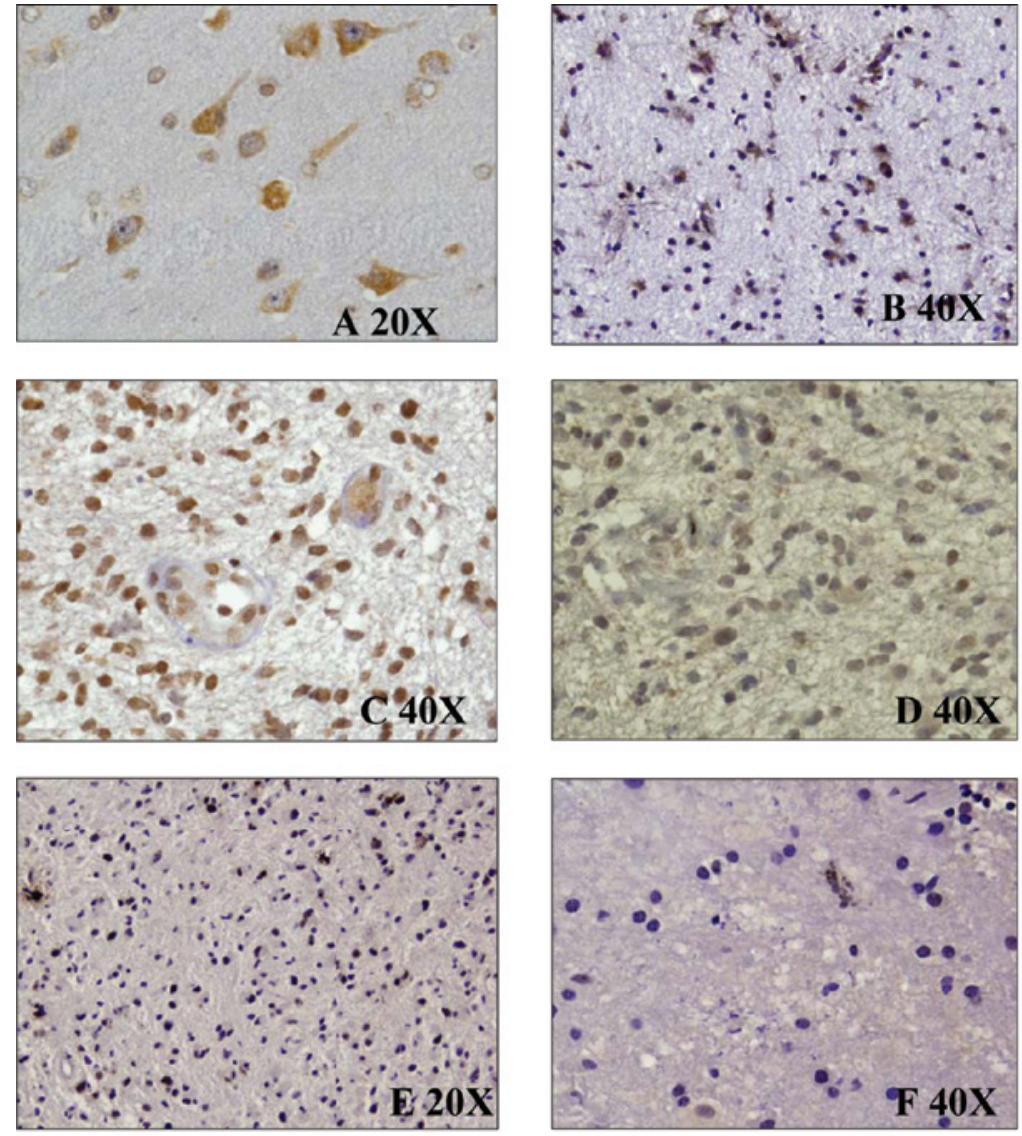

Figure 2. (A) VEGF cytoplasmic staining in group 2 (x20). (B) VEGF in RG, IRS=6 (x40). (C) VEGF in GC, immunoreaction in 70\% of cells (x40); (D) survivin in GC, nuclear reaction in 5\% of cells (x40); (E) p53 in RG, nuclear reaction in 25\% of cells (x20); (F) p53 in GC, nuclear reaction in 5\% of cells (x40). 
口EGFR $\square$ VEGF $\square$ HIF1- $\alpha$ BCl-2 $\square$ Survivin $\square$ p53

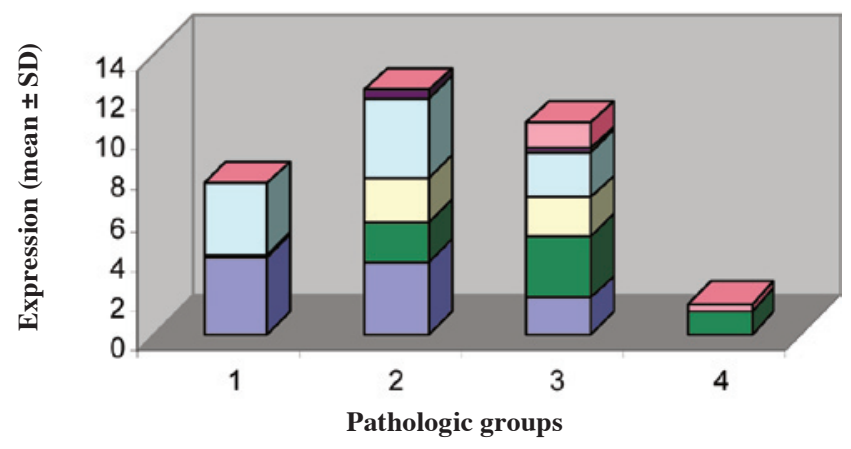

Figure 3. Semi-quantitative analysis of the expression of EGFR, VEGF, HIF1- $\alpha$, Bcl-2, survivin and p53 antibodies in 28 human tissue samples. The $\mathrm{X}$ axis represents the pathologic groups analyzed (group 1, low-grade ACs; group 2, peripheral area of high-grade ACs; group 3, GC; group 4, RG) and the $\mathrm{Y}$ axis represents the mean of the expression values of the antibodies.

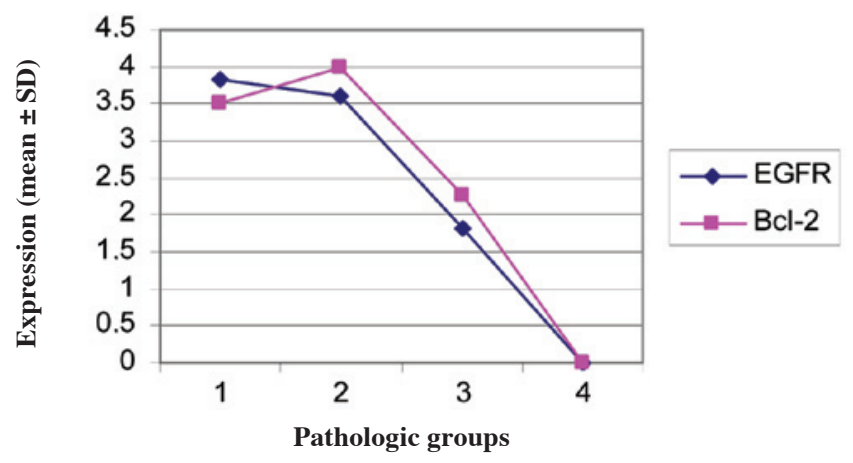

Figure 4. Expression of EGFR and $\mathrm{Bcl}-2$. The $\mathrm{X}$ axis represents the pathologic groups analyzed (group 1, low-grade ACs; group 2, peripheral area of highgrade ACs; group 3, $\mathrm{GC}$; group 4, $\mathrm{RG}$ ) and the $\mathrm{Y}$ axis represents the mean of the semi-quantitative expression values for EGFR and Bcl-2, respectively.

molecules assessed immunohistochemically does not appear to differentiate astroglial neoplasia from reactive astrogliosis, at least in the sample size currently used.

\section{Discussion}

None of the well-known prognostic factors of gliomas (age, Karnofsky Performance Status, histology grading or contrast enhancement) are good predictive indicators in GCs. This may be due in part to the small number of patients who present with this lesion, but nevertheless suggests that these prognostic markers are less reliable in GC than in common gliomas. Consequently, there is a great need to identify novel prognotic factors for GCs. RG is a dynamic event that leads to a densely interwoven glial scar composed of numerous cells, including reactive astrocytes, microglia, macrophages and endothelial cells, and is accompanied by a neoangiogenic response caused by increased VEGF secretion by quiescent reactive astrocytes $(22,32,33)$.

By means of IHC, VEGF homodimeric glycoprotein immunoreactivity was observed in the form of a cytoplasmic staining pattern in the endothelial, nerve and tumoral cells in the four groups included in the present study.
The EGFR pathway controls the phenotypic characteristics of astrocytes. In the developing CNS, activation of the EGFR cascade incites astrocyte differentiation. In the adult CNS, the EGFR cascade is absent from astrocytes, but is highly up-regulated and activated following neuronal insults (24).

The activation of EGFR, detected as the phosphorylated form of EGFR by an antibody raised against the $170 \mathrm{KD}$ wild-type EGFR and the $145 \mathrm{kD}$ mutant form of the receptor (EGFR VIII), was absent in the RG samples studied. EGFR values measured by IHC were significantly higher in groups 1 and 2 than in group 4 (Mann-Whitney $U$ test, $p=0.015$ and $\mathrm{p}=0.030$, respectively). These results suggest that EGFR expression is a candidate novel marker that may be useful in the differential diagnosis between reactive astrocytes and lowgrade or peripheral areas of high-grade gliomas.

The Bcl-2 mitochondrial oncoprotein, a pro-survival molecule that arrests cells in the G0/G1 phase of the cell cycle, is known to be involved in gliomas (34). Bcl-2 is widely expressed during embryogenesis within somatic cells, including those of neural origin (35). Thus, it appears to be more strongly expressed in cells that are actively differentiating into mature tissues, indicating a role for Bcl-2 in tissue morphogenesis and clonal selection. The presence of Bcl-2 in mature neurons has been postulated to reflect the effect of neurotrophic factors that help maintain a stable neuronal population (35).

In the present study, $\mathrm{Bcl}-2$ protein was found to be expressed in all the groups except the group 4 RGs. The differences in Bcl-2 expression were statistically significant between group 3 and group $4(\mathrm{p}=0.005)$. This suggests that $\mathrm{Bcl}-2$ expression is uniquely associated with neoplastic transformation.

Survivin, another anti-apoptotic protein that operates via a Bcl-2-independent pathway, is a structurally unique member of the IAP family that acts as a suppressor of apoptosis, reducing the generation of active caspases and playing a central role in cell division. This protein is undetectable in normal differentiated tissues (36), but is massively up-regulated in human tumors and is involved in cancer progression and treatment resistance. As a result, survivin is currently undergoing extensive investigation as a novel therapeutic target $(37,38)$.

In the present study, nuclear survivin protein expression levels were only detected in groups 2 and 3. There was no statistical significance in survivin expression between any of the groups studied.

IHC for the detection of p53 protein has been used to determine whether it is possible to distinguish between malignant tumors and morphologically-similar benign processes. Immunoreactions to DO-7 among the samples were observed only in the group 3 GCs. Normal p53 protein has a short half-life (5-30 min) due to its rapid turnover. Mutation of the gene usually leads to the production of a more stable protein that can be detected via IHC staining, although a relationship between gene mutations and immunoreactivity is not always present $(39,40)$. Despite a variety of existing techniques for the analysis of tumor tissue, none of these methods are applicable when using small fixed paraffin-embedded specimens, which make up the bulk of pathologic specimens, thus making differentiation difficult.

The lack of p53 immunoreactivity in a variety of reactive astroglial lesions may help to establish a diagnosis in cases 
where the existing techinques are insufficient, by identifying hypertrophic astrocytes without atypia or mitosis. Aberrant protein expression in human glial tumors is associated with progression from low- to high-grade ACs (41). Therefore, if the TA core is immunoreactive with p53 antibodies, a malignant process should be suspected.

There are discrepancies between the results of our study and previous results, which may be due to the use of different methodologies, such as antibody type, antibody specificity, positivity evaluation, antigenal retrieval methods and, in glioma samples, genetic heterogeneity (35).

Several techniques besides histology have been applied to distinguish gliomas from gliosis: microsatellite analysis to examine loss of heterozygosity (17), fluorescent in situ hybridization (FISH) (42), in situ hybridization (43), comparative genomic hybridization $(44,45)$, RNA microarray expression analysis (46), certain proteomic techniques (47) and microdissection techniques, coupled with polymerase chain reaction amplification (48).

The results of the present study indicate that the TA approach designed here has the potential to provide discriminating objective information with which to differentiate between RGs and glioma, as it permits several areas of tumors to be analyzed using a variety of antibodies. In order to clarify the implications of molecular expression on tissue arrays and its differentiating capabilities, further research is required.

\section{Acknowledgements}

This study was supported by a Grant from Shering-Plough (Spain). Silvia Díaz Prado is supported by an Isidro Parga Pondal research contract by Xunta de Galicia (A Coruña, Galicia, Spain). Cancer research in our laboratory is supported by the Fundación A Coruña (CHUAC).

\section{References}

1. Da Cunha A, Jefferson JJ, Tyor WR, Glass JD, Jannotta FS and Vitkovic L: Gliosis in human brain: relation ship to size but not other properties of astrocytes. Brain Res 600: 161-165, 1993.

2. Levin N, Gomori JM and Siegal T: Chemotherapy as initial treatment in gliomatosis cerebri. Neurology 63: 354-356, 2004.

3. Filley CM, Kleinschmidt-DeMasters BK, Lillehei KO, Damek DM and Harris JG: Gliomatosis cerebri: neurobehavioral and neuropathological observations. Cog Behav Neurol 16: 149-159, 2003.

4. Nishioka H, Ito $\mathrm{H}$ and Miki T: Difficulties in the antemorten diagnosis of gliomatosis cerebri. Neurology 63: 354-356, 2004.

5. Herrlinger U, Felsberg J, Küker W, et al: Gliomatosis cerebri: molecular pathology and clinical course. Ann Neurol 52: 390-399, 2002.

6. Bendszus M, Warmuth-Metz M, Klein R, Burger R, Shichor C, Tonn JC and Solymosi L: MR Spectroscopy in gliomatosis cerebri. AJNR Am J Neuroradiol 21: 375-380, 2005.

7. Suzuki T, Izumoto S, Fujimoto $\mathrm{Y}$, Maruno M, Ito $\mathrm{Y}$ and Yoshimine T: Clinicopathological study of cellular proliferation invasion of neural cell adhesion molecule L1 in tumour and invasion in gliomatosis cerebri: important role of neural cell adhesion molecule L1 in tumour invasion. J Clin Pathol 58 166-171, 2005.

8. Taillibert S, Chodkiewicz C, Laigle-Donadey F, Napolitano M, Cartalat-Carel S and Sanson M: Gliomatosis cerebri: a review of 296 cases from the ANOCEF database and the literature. J Neurooncol 76: 201-205, 2006.

9. Yamada SM, Hayashi Y, Takahashi H, Teramoto A, Matsumoto K and Yamada S: Histological and genetic diagnosis of gliomatosis cerebri: case report. J Neurooncol 52: 237-240, 2001.
10. Braeuninger S, Scheneider-Stock R, Kirches E, Krause G, Mawrin C and Dietzmann K: Evaluation of molecular genetic alterations associated with tumor progression in a case of gliomatosis cerebri. J Neurooncol 82: 23-27, 2007.

11. Hecht BK, Turc-Carel C, Chatel M, Loujon M, Roche JL, Gioanni J, Hecht F and Gaudray P: Chromosomes in gliomatosis cerebri. Genes Chromosomes Cancer 14: 149-153, 1995.

12. Mawrin C: Molecular genetic alterations in gliomatosis cerebri: what can we learn about the origin and course of the disease? Acta Neuropathol 110: 527-536, 2005.

13. Mawrin C, Kirches E, Scheneider-Stock R, et al: Alterations of cell cycle regulators in gliomatosis cerebri. J Neurooncol 72: $115-122,2005$.

14. Mawrin C, Lins H, Kirches E, Schildhaus HU, Scherlach C, Kanakis D and Dietzmann K: Distribution of p53 alterations in a case of gliomatosis cerebri. Hum Pathol 34: 102-106, 2003.

15. Ware ML, Hirose Y, Scheithauer BW, Yeh RF, Mayo MC, Smith JS, Chang S, Cha S, Tihan T and Feuerstein BG: Genetic aberrations in gliomatosis cerebri. Neurosurgery 60: 150-158, 2007.

16. Kleihues P, Louis DN, Scheithauer BW, Rorke LB, Reifenberger G, Burger PC and Cavenee WK: The WHO classification of tumors of the nervous system. J Neuropathol Exp Neurol 61: 215-225, 2002

17. Finkelstein SD, Mohan D, Hamilton RL, Sasatomi E, Swalsky PA and Lieberman FS: Microdissection-based genotyping assists discrimination of reactive gliosis from glioma. Am J Clin Pathol 121: 671-678, 2004.

18. Schiffer D, Cavalla P, Dutto A and Borsotti L: Cell proliferation and invasion in malignant gliomas. Anticancer Res 17: 61-69, 1997.

19. Ross IB, Robitaille Y, Villemure JG and Tampieri D: Diagnosis and management of gliomatosis cerebri: recent trenes. Surg Neurol 36: 431-440, 1991

20. Gillett C, Springall RJ, Barnes DM and Hanby AM: Multiple tissue core arrays in histopathology research: a validation study. J Pathol 192: 549-553, 2000.

21. Kononen J, Bubendorf L, Kallioniemi A, Bärlund M, Schraml P, Leiqhton S, Torhorst J, Mihatsch MJ, Sauter G and Kallioniemi OP: Tissue microarrays for highthroughput molecular profiling of tumor specimens. Nat Med 4: 844-847, 1998.

22. Salhia B, Angelov L, Roncari L, Wu X, Shannon P and Guha A: Expression of vascular endothelial growth factor by reactive astrocytes and associated neoangiogenesis. Brain Res 883: 87-97, 2000.

23. Rabchevsky AG, Weinitz JM, Coulpier M, Fages C, Tinel M and Junier MP: A Role of transforming growth factor $\alpha$ as an inducer of astrogliosis. J Neurosci 18: 10541-10552, 1998.

24. Eng LF, Yu A and Lee YL: Astrocytic response to injury. Progress Brain Research 94: 353-365, 1998.

25. Liu B and Neufeld AH: Activation of epidermal growth factor receptors in astrocytes: from development to neural injury. J Neuroscience Res 85: 3523-3529, 2007.

26. Plate KH, Breirer G, Weich HA and Risau W: Vascular endothelial growth factor is a potential tumor angiogenesis factor in human gliomas in vivo. Nature 359: 845-848, 1992.

27. Vojtesec B, Bártek J, Midgley CA and Lane DP: An immunochemical analysis of the human nuclear phosphoprotein p53. New monoclonal antibodies and epitope mapping using recombinant p53. J Immunol Methods 151: 237-244, 1992.

28. Hussein MR and Ismael HH: Alterations of p53, Bcl-2, and $\mathrm{hMSH} 2$ protein expression in the normal breast, benign proliferative breast disease in situ and infiltrating ductal breast carcinomas in the Upper Egypt. Cancer Biol Ther 3: 983-988, 2004.

29. Weller M, Frei K, Groscurth P, Krammer PH, Yonekawa Y and Fontana A: Anti-Fas/APO-1 antibody-mediated apoptosis of cultured human glioma cells. Induction and modulation of sensitivity by cytokines. J Clin Invest 94: 954-964, 1994.

30. Krishna M, Smith TW and Recht LD: Expression of Bcl-2 in reactive and neoplastic astrocytes: lack of correlation with presence or degree of malignancy. J Neurosurg 83: 1017-1022, 1995.

31. Söling A, Plugge EM, Schmitz M, Weigle B, Jacob R, Illert J, Holzhausen $\mathrm{HJ}$ and Rainov N: Autoantibodies to the inhibitor of apoptosis protein survivin in patients with brain tumors. Int J Oncol 30: 123-128, 2007.

32. Zhen HN, Zhang X, Hu PZ, Yang TT, Fei Z, Zhang JN, Fu LA, He XS, Ma FC and Wang XL: Survivin expression and its relation with proliferation, apoptosis, and angiogenesis in brain gliomas. Cancer 104: 2775-2783, 2005. 
33. Hussein MR, El-Ghorori RM and El-Rahman YG: Alterations of $\mathrm{p} 53, \mathrm{Bcl}-2$, and $\mathrm{MSH} 2$ protein expression in the normal brain tissues, gliosis, and gliomas. Int J Exp Path 87: 297-306, 2006.

34. Lu QL, Poulsom R, Wong L and Hanby AM: Bcl-2 expression in adult and embryonic non-haematopoietic tissues. J Pathol 169: 431-437, 1993

35. Hockenbery DM, Zutter M, Hickey W, Nahm $M$ and Korsmeyer SJ: Bcl-2 protein is topographically restricted in tissues characterized by apoptotic cell death. Proc Natl Acad Sci USA 88: 6961-6965, 1995.

36. Altieri DC: Validating survivin as a cancer therapeutic target. Nat Rev Cancer 3: 46-54, 2003.

37. Blanc-Brude OP, Mesri M, Wall NR, Plescia J, Dohi T and Altieri DC: Therapeutic targeting of the survivin pathway in cancer: initiation of mitochondrial apoptosis and supression of tumor-associated angiogenesis: Clin Cancer Res 9: 2683-2692, 2003.

38. Pennati M, Folini $\mathrm{M}$ and Zaffaroni N: Targeting survivin in cancer therapy. Expert Opin Ther Targets 12: 463-476, 2008.

39. Hall PA, McKee PH, Menage HD, Dover R and Lane DP High levels of p53 protein in UV irradied normal human skin. Oncogene 8: 203-207, 1993.

40. Kuerbitz SJ, Plunket BS, Walsh WV and Kastan MB: Wild type p53 is a cell cycle checkpoint determinant following irradiation. Proc Natl Acad Sci USA 89: 7491-7495, 1992.

41. Rasheed BK, McLendon RE, Herndon JE, Friedman HS, Friedman AH, Bigner DD and Bigner SH: Alterations of the TP 53 gene in human gliomas. Cancer Res 54: 1324-1330, 1994.
42. Okada Y, Hurwitz EE, Esposito JM, Brower MA, Nutt CL and Louis DN: Section pressures of TP53 mutation and microenvironmental location influence epidermal growth factor receptor gene amplification in human glioblastomas. Cancer Res 63: 413-416, 2003.

43. Wessels PH, Hopman AH, Ummelen MI, Krijne-Kubat B, Ramaekers FC and Twijnstra A: Differentiation between reactive gliosis and diffuse astrocytoma by in situ hybridization. Neurology 56: 1224-1227, 2001.

44. Bigner SH, Mark J, Burger PC, Mahaley MS Jr, Bullard DE, Muhlbaier LH and Bigner DD: Specific chromosomal abnormalities in malignant human gliomas. Cancer Res 48: 405-411, 1998.

45. Rey JA, Bello MJ, de Campos JM, Kusak ME and Moreno S: Cytogenetic follow-up from direct preparation to advanced in vitro passages of a human malignant glioma. Cancer Genet Cytogenet 41: 175-183, 1989.

46. Sallinen SL, Sallinen PK, Haapasalo HK, Helin HJ, Helen PT, Schraml P, Kallioniemi OP and Kononen J: Identification of differentially expressed genes in human gliomas by DNA microarray and tissue chip techniques. Cancer Res 60: 6617-6622, 2000.

47. Rohlff C and Southan C: Proteomic approaches to central nervous system disorders. Curr Opin Mol Ther 4: 251-258, 2002.

48. Pollack IF, Hamilton RL, Finkelstein SD, Campbell JW, Martinez AJ, Sherwin RN, Bozik ME and Gollin SM: The relationship between TP53 mutations and overexpression of p53 and prognosis in malignant gliomas of childhood. Cancer Res 57: 304-309, 1997. 